\title{
Geographical Information System Complaints on Damage to Roads and Bridges in Semarang City
}

\author{
Stefanus Lintang Timur Aji Pamungkas ${ }^{1}$, \\ Albertus Dwiyoga Widiantoro ${ }^{2}$ Hendra Prasetya ${ }^{3}$ \\ ${ }^{1,2,3}$ Departmen of Information System, Soegijapranata Catholic University \\ 1,2,3Jl. Pawiyatan Luhur Sel. IV No.1, Bendan Duwur, Kota Semarang, Jawa Tengah 50234 \\ ${ }^{1}$ lintangtimur915@gmail.com \\ 2yoga@unika.com \\ ${ }^{3}$ hendra@unika.ac.id
}

\begin{abstract}
In a world that has developed towards digital, especially in the field of information and communication technology. Using technology is very useful in easing human work. In managing information on damage to roads and bridges in Semarang City, it can be facilitated by visual representation. Processing in the form of maps using leafletjs is a lightweight and easy to use javascript framework, the advantage of leafletjs is that there are many third parties that are easy to add to the main function of the leafletjs framework. After making an application it will distribute 30 questionnaires to the general public so that an application that is easy to use in the long term can be obtained.
\end{abstract}

Keywords - leafletjs, openstreetmap, laravel, sistem informasi geografis.

\section{I.INTRODUCTION}

Roads and bridges as one of the main infrastructures in the transportation sector in Semarang City have a major role in supporting the realization of equitable regional development that is carried out sustainably. In monitoring the condition of roads and bridges, a Geographical Information System for roads and bridges in Semarang is needed that has graphic capabilities in its presentation. According to Charter Denny (2004) geographic information systems are systems that are designed to work with spatially referenced data or geographic coordinates. GIS has the ability to perform data processing and perform certain operations by displaying and analyzing data. With the existence of a geographical information system, it is expected that the problems of roads and bridges can be worked out efficiently[1].

Development of an area is an important thing for the development of an area. No matter how great the potential of an area if there is no development of the region will still not be touched by the name of development and progress. The main thing in the development of an area is in the form of road access. Because, the road is very influential on the smooth and economic progress of a region.

In the city of Semarang in various road segments there is a lot of road damage that disrupts motor vehicle activity, which results if the rider is not in a careless condition, especially motorcyclists, something undesirable can occur like a great shock, causing motorcyclists to fall. Road damage varies, some are small, medium to large enough.

One way to answer the above needs is to present all information about roads and bridges through a road network map in a Geographic Information System application. Regarding the geographical information system of road and bridge networks, data that is needed to be displayed include information on historical data of roads and bridges and their conditions [2]. GIS offers a spatial data integration system that is textual data which is a comprehensive description of the object and its relevance. [3] In this study to 
build and design a geographic information system to display field information in the Semarang City area utilizing the OpenStreetMap (OSM) application that is displayed into a web application. By using OpenStreetMap can provide geospatial information with a variety of diverse information, such as the name of the road, the type of road, what roads are included in the building, administrative boundaries, museums, etc.[4]

There are various types of digital maps that are on the internet, but most cannot freely do technical things. So as to make the public, government, researchers, and innovators unable to use the data in the map freely. Through OSM data can be downloaded for free and open for later distribution. [5] For an interactive display using javascript leaflets, where the leaflet is a leading javascript library that is open source to build interactive and mobile friendly maps. [6] Leaflets also support Geojson. Geojson is a data format based on Json (Javascript Object Notation) that can accommodate geographic elements into Json.

With this geographic information system maps and data can be processed automatically by a computer. Geographic information systems can integrate vector map data and digital images. From these capabilities that can distinguish geographic information systems with other information systems, and make geographic information systems more useful in providing information that approaches the real world and strategic planning. This kind of thing motorists should be able to report to the Semarang city transportation department, so that the government can repair road damage, so driving activities are not too careful.

\section{II.LITERATURE REVIEW A. Open Street Map (OSM) \\ Open Street Map (OSM) is a GIS Web product that is operated on smartphone}

systems based on the Android operating system. OSM was developed because part of it was made and optimized for free distribution. This project is maximized because some of the existing online map services have copyright and restrictions on paid applications that prevent people from applying them independently and creatively. [7] The Open Street Map API uses the Representational State Transfer (REST) web service style. In requesting requests to the REST through the Uniform Resource Identifier (URI) [8]. Through the Open Data Commons Open Database License 1.0 OSM contributors can own, modify, and share map data widely.[9]

\section{B. Geographic Information Systems}

Geographic Information Systems according to Charter Denny (2004), is a system designed to work with spatially referenced data or geographic coordinates. GIS has the ability to perform data processing and perform certain operations by displaying and analyzing data. GIS applications are currently growing not only by number of applications but also by the variety of applications. The development of GIS applications in the future will lead to andoridbased applications better known as mobile GIS.

This is because the development of applications in the network environment has shown great potential in relation to geo information. An example is the online map of a city where users can easily search for a desired location online through the internet network without knowing the geography of the user.

Data models that are often used in spatial data are vector types, because these spatial data can describe the shape of a region's conditions in great detail.[10] According to Esri (1990), that a geographic information system is an organized collection of software, hardware, geographic data, and personnel that are efficiently designed to store, change, manipulate, analyze, and display all forms of geographic reference information.[11] 


\section{Laravel}

Laravel is one of the frameworks for developing web applications with expressive and elegant syntax and provides solutions for development by facilitating common tasks in most large web projects. Laravel has a number of helpful functions such as Bundle, Eloquent ORM, Application Logic, Reverse Routing, Auto Loading Class, etc. The implementation of the Laravel framework is based on the latest research where web technology has not yet been applied. Exploration of Laravel's framework in this paper includes the implementation of the MVC concept, Eloquent ORM, Blade Templating, and Bundles installation that supports system functions[12].

\section{Definition of Road Networks}

Based on Law No. 13 of 1980 concerning Roads, states that: Roads are a land transportation infrastructure in any form covering all parts of the road including its complementary buildings and equipment intended for traffic..[13] Roads have important functions, one of which is in the economic field. In the economic field, roads have an important role in encouraging business development to achieve equitable levels of regional development. Roads are a united road network system and connect with regions that are in a hierarchical relationship. On the official website of the West Java Regional Government Office of Bina Marga, there are several types of roads based on their functions, which are as follows:[13]

1. Arterial Roads: Roads that can serve major transportation with long-distance travel destinations, high average speeds and the number of access roads that are efficiently restricted.

2. Collector Roads: Public roads that serve the service of dividing transport with the characteristics of medium-distance travel, moderate average speed accompanied by a limited number of access roads.
3. Local Roads: Roads that serve local transportation for the purpose of short distance travel, low speed, and unlimited number of roads.

4. Environmental Road: Road designed for short distance travel at low speeds. For example like the road in residential housing that is around us.

In addition, the road can be distinguished based on the status of the road or road segment, as follows:

1. National Road: is a road built from the State Budget. Arterial roads \& collector roads, toll roads included in national roads.

2. Regency Road: is a road that is built based on the relevant Regency APBD. The road that connects the district capital with the capital of the District, the capital of the district with the center of the village, between the capital of the District. [14]

3. Provincial Roads: The primary road network system that connects provincial capitals with district / city capitals.

\section{E. Leafletjs}

Leaftletjs is an Open Source Javascript that helps in the development of making interactive maps on web pages easily. Leaflets provide a function to add a marker, a popup. The advantage of the leaflet lies in accessing the plugin which makes it easy to use third parties such as animating, heating maps, manipulating layers, displaying coordinates.[9] 


\section{III.METHODOLOGY}

\section{A. Research methodology}

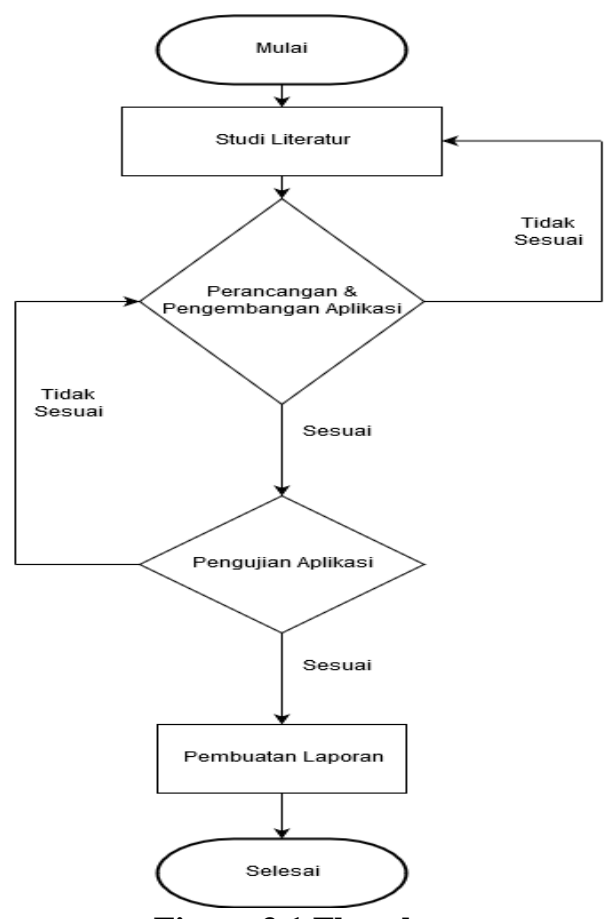

Figure 3.1 Flowchart

\section{IV.RESULTS AND DISCUSSION}

Testing the application used in this thesis using a statistical test by distributing 30 questionnaires to the general public.

\section{A. Validity test}

The validity results are processed using SPSS which can be seen in Figure 2. PE2 is below 0.5 , then it must be removed. These results can be seen in Figure 3.

\begin{tabular}{|l|r|r|r|r|}
\hline Validitas & 1 & 2 & 3 & 4 \\
\hline PE1 & .632 & .303 & .305 & .449 \\
\hline PE2 & .472 & -.139 & .390 & .512 \\
\hline PE3 & .801 & .199 & .262 & .055 \\
\hline EE1 & .075 & .199 & .091 & .885 \\
\hline EE2 & .114 & .517 & .217 & .488 \\
\hline EE3 & .047 & .588 & .335 & .627 \\
\hline SI1 & .078 & .707 & .223 & .168 \\
\hline SI2 & .532 & .623 & .370 & .119 \\
\hline SI3 & .267 & .824 & .145 & .177 \\
\hline PU1 & .114 & .324 & .851 & .243 \\
\hline PU2 & .205 & .078 & .866 & .134 \\
\hline PU3 & .174 & .439 & .679 & .189 \\
\hline B1 & .822 & .139 & .039 & .186 \\
\hline BI2 & .582 & .068 & .147 & .594 \\
\hline BI3 & .602 & .510 & .365 & .141 \\
\hline
\end{tabular}

Figure 4.1 Uji validitas

\begin{tabular}{|l|r|r|r|r|}
\hline \multirow{2}{*}{} & \multicolumn{5}{|c|}{ Rotated Component Matrix } \\
\cline { 2 - 5 } & 1 & \multicolumn{3}{|c|}{ Component } \\
\hline PE1 & .624 & .424 & .238 & .357 \\
PE3 & .805 & .289 & .193 & -.016 \\
EE1 & .078 & .184 & .113 & .896 \\
EE2 & .130 & .625 & .164 & .412 \\
EE3 & .076 & .553 & .361 & .645 \\
SI1 & .081 & .598 & .299 & .224 \\
SI2 & .550 & .581 & .387 & .130 \\
SI3 & .277 & .816 & .160 & .168 \\
PU1 & .125 & .318 & .856 & .225 \\
PU2 & .228 & -.009 & .902 & .174 \\
PU3 & .202 & .464 & .657 & .157 \\
BI1 & .850 & -.036 & .108 & .300 \\
BI2 & .581 & -.025 & .194 & .651 \\
BI3 & .621 & .455 & .384 & .162 \\
\hline
\end{tabular}

Figure 4.2 Hasil PE2 dihilangkan

There are values below 0.5, then EE1 needs to be removed, these results can be seen in Figure

\begin{tabular}{|l|r|r|r|}
\multicolumn{4}{c|}{ Rotated Component Matrix } \\
\hline & \multicolumn{3}{|c|}{ Component } \\
\cline { 2 - 4 } & 1 & 2 & \multicolumn{1}{c|}{3} \\
\hline PE1 & .486 & .671 & .252 \\
PE3 & .235 & .768 & .165 \\
EE2 & .717 & .196 & .189 \\
EE3 & .711 & .196 & .417 \\
SI1 & .649 & .105 & .288 \\
SI2 & .572 & .540 & .364 \\
SI3 & .826 & .276 & .136 \\
PU1 & .367 & .156 & .861 \\
PU2 & .039 & .257 & .909 \\
PU3 & .477 & .212 & .654 \\
BI1 & .031 & .896 & .122 \\
BI2 & .165 & .712 & .252 \\
BI3 & .465 & .622 & .367 \\
\hline
\end{tabular}

Figure 4.3 Hasil final uji validitas

\section{B. Reliability Test}

\begin{tabular}{|l|l|l|}
\hline Variable & $\begin{array}{l}\text { Cronbach's } \\
\text { Alpha }\end{array}$ & Description \\
\hline PE & 0.835 & Good \\
\hline EE & 0.796 & Acceptable \\
\hline SI & 0.834 & Good \\
\hline PU & 0.872 & Good \\
\hline BI & 0.820 & Good \\
\hline
\end{tabular}

Figure 4.4 Reliability test 


\section{Corelation Test}

Correlation test can be produced that each statement is interconnected or correlated with other statements, which are shown in the star symbol (*). These results can be seen in Figure 5.

\begin{tabular}{|ll|r|r|r|r|r|}
\hline & & \multicolumn{1}{c|}{ Correlations } \\
\hline \multirow{2}{*}{ APE } & APE & \multicolumn{1}{c|}{ AEE } & ASI & APU & \multicolumn{1}{c|}{ ABI } \\
& Pearson Correlation & 1 & $.539^{*}$ & $.529^{*}$ & $.551^{*}$ & $.679^{*}$ \\
& Sig. (2-tailed) & & .002 & .003 & .002 & .000 \\
& $\mathrm{~N}$ & 30 & 30 & 30 & 30 & 30 \\
\hline AEE & Pearson Correlation & $.539^{* *}$ & 1 & $.602^{*}$ & $.576^{*}$ & $.527^{*}$ \\
& Sig. (2-tailed) & .002 & & .000 & .001 & .003 \\
& N & 30 & 30 & 30 & 30 & 30 \\
\hline ASI & Pearson Correlation & $.529^{*}$ & $.602^{*}$ & 1 & $.598^{*}$ & $.608^{*}$ \\
& Sig. (2-tailed) & .003 & .000 & & .000 & .000 \\
& N & 30 & 30 & 30 & 30 & 30 \\
\hline APU & Pearson Correlation & $.551^{*}$ & $.576^{*}$ & $.598^{*}$ & 1 & $.527^{*}$ \\
& Sig. (2-tailed) & .002 & .001 & .000 & & .003 \\
& N & 30 & 30 & 30 & 30 & 30 \\
\hline ABI & Pearson Correlation & $.679^{*}$ & $.527^{*}$ & $.608^{*}$ & $.527^{*}$ & 1 \\
& Sig. (2-tailed) & .000 & .003 & .000 & .003 & \\
& N & 30 & 30 & 30 & 30 & 30 \\
\hline
\end{tabular}

**. Correlation is significant at the 0.01 level (2-tailed).

Figure 4.5 Corelation test

\section{CONCLUSION}

From these results the following conclusions are obtained:

1. The design of a Geographic Information System application for Semarang City Road and Bridge Damage Complaints Complaints starts from designing the initial display framework, followed by designing a database, so that it knows what entities need to be related and easy to develop.

2. Implementation of the Geographic Information System Application for Semarang City Road and Bridge Damage Complaints so that the damage can be overcome by inputting reports through report input filled with report subjects, road names, damage categories, and uploading field evidence for the damage information.

3. The impact resulting from the questionnaire 30 respondents of the application of the Geographic Information System for Complaints of Roads and Bridges in Semarang City found aspects of Performance Expectancy, Effort
Expectancy, Social Influence, Satisfaction, and Behavior Intension correlated. Which means the application meets the needs of the user.

\section{REFERENCE}

[1] P. Infrastruktur and J. Dan, "FaktorFaktor Yang Mempengaruhi Pembangunan Infrastruktur (Jalan Dan Jembatan ) Di Kecamatan Kampar Kiri Hulu Kabupaten Kampar Tahun 20112013," vol. 3, no. 1, pp. 1-13, 2013.

[2] D. I. K. Wonogiri, "Sistem Informasi Geografis Jalan dan Jembatan Kabupaten Wonogiri," 2016.

[3] D. Pembimbing, T. Informatika, U. Dian, and N. Semarang, "Rancang bangun sistem informasi geografis jalan kabupaten pada kabupaten kudus," pp. 18.

[4] A. Niam, A. Suprayogi, and M. Awaluddin, "Aplikasi OpenStreetMap untuk Sistem Informasi Geografis Kantor Pelayanan Umum: Studi Kasus Kota 
Salatiga," J. Geod. Undip, vol. 3, no. 4, pp. 150-157, 2013.

[5] N. K. Dewi, "Pemanfaatan OPenStreetMaps dan Sistem Informasi Geografis untuk Menyusun Rekomendasi Manajemen Jalan di Sebgian Kota Serang," J. Bumi Indones., vol. 6, no. 3, pp. 1-10, 2017.

[6] M. I. Wardana and M. Jazman, "Rancang Bangun Sistem Informasi Geogafis Pemetaan Ruang Ujian Menggunakan Bootstrap dan Leaflet . js ( Studi Kasus : Fakultas Sains dan Teknologi UIN Suska Riau )," no. June, pp. 18-19, 2017.

[7] B. Atmadja and R. Munir, "Pencarian Rute Perjalanan Terpendek pada Open Street Map dengan Algoritma A *," 2009.

[8] S. Ia, G. Ica, and S. I. N. Ica, "Penggunaan Teknologi Openstreetmap Untuk GIS Fasilitas Pelayanan Umum Berbasis Android (Studi Kasus Kota Palu)," no. score 3, pp. 1-34, 2001.

[9] E. J. Tanjaya et al., "Pemetaan Surabaya Heritage Dengan Geographic Information System," pp. 1-4. 